\title{
A New Design Strategy and Diagnostic to Tailor the DNA- Binding Mechanism of Small Organic Molecules and Drugs
}

Phi Doan, ${ }^{\dagger}$ Demar R. G. Pitter, ${ }^{\ddagger}$ Andrea Kocher, ${ }^{\dagger}$ James N. Wilson, ${ }^{\ddagger}$ Theodore Goodson III ${ }^{*}{ }^{\dagger}$

${ }^{\dagger}$ Department of Chemistry, University of Michigan, Ann Arbor, MI 48109

${ }^{\ddagger}$ Department of Chemistry, University of Miami, Coral Gables, FL 33146

\section{Supplementary Information}
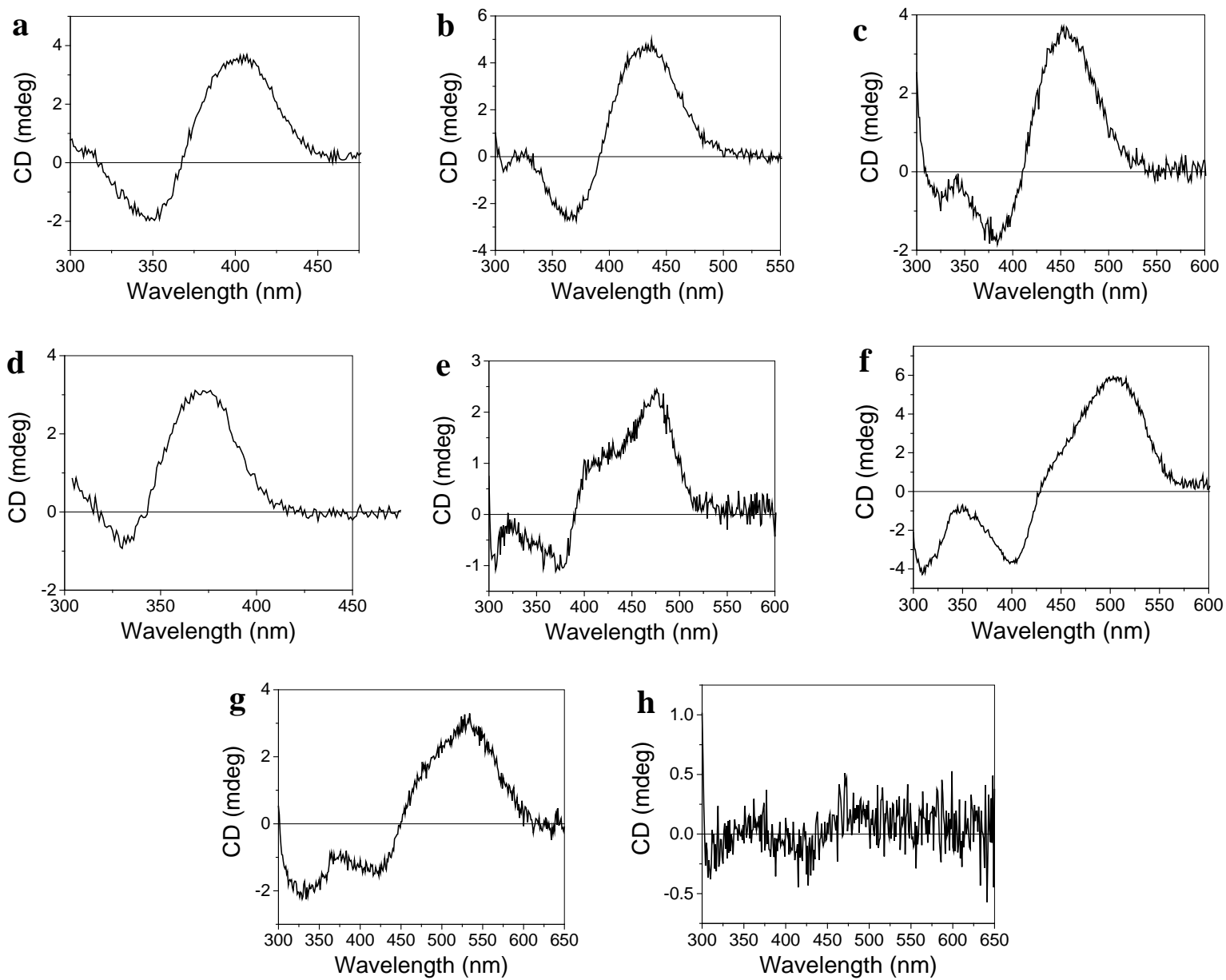

Figure S1. CD spectra of (a) 1, (b), 2, (c) 3, (d) 4, (e) 5, (f) 6, (g) 7, (h) 8 in the presence of DNA. 

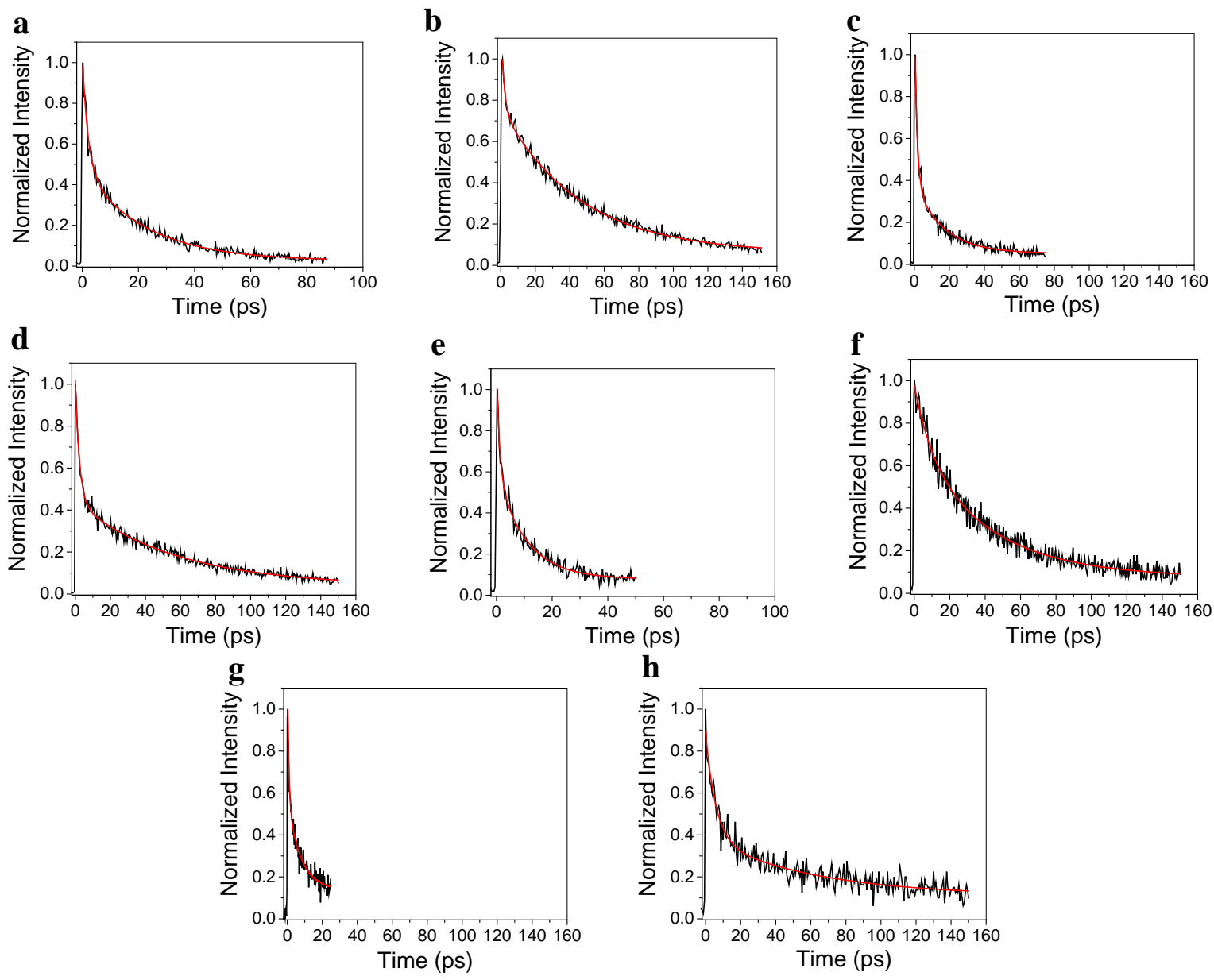

Figure S2. Fluorescence lifetime of (a) 1, (b), 2, (c) 3, (d) 4, (e) 5, (f) 6, (g) 7, (h) 8 in the absence of DNA. 

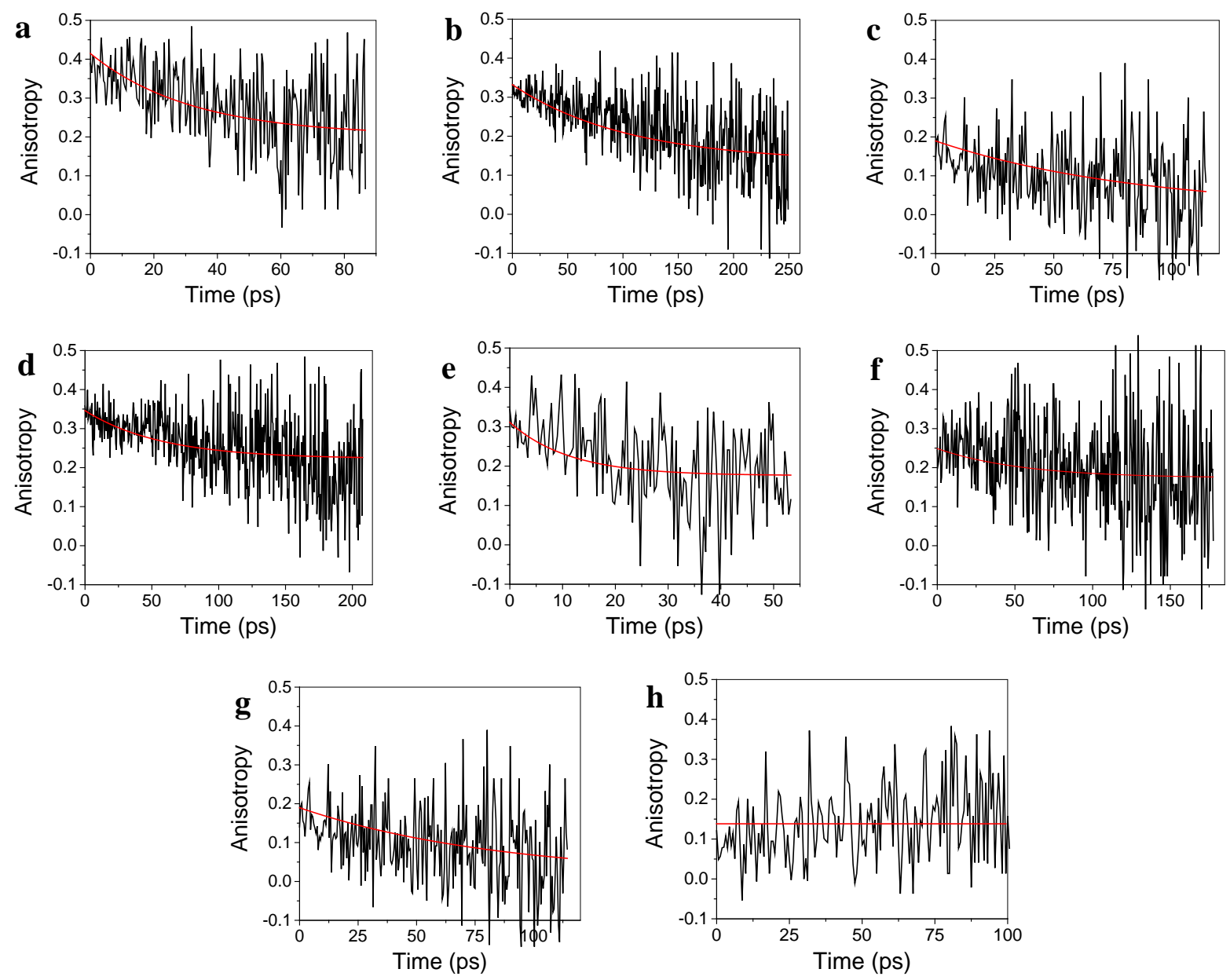

Figure S3. Fluorescence anisotropy of (a) 1, (b), 2, (c) 3, (d) 4, (e) 5, (f) 6, (g) 7, (h) 8 in the absence of DNA. 

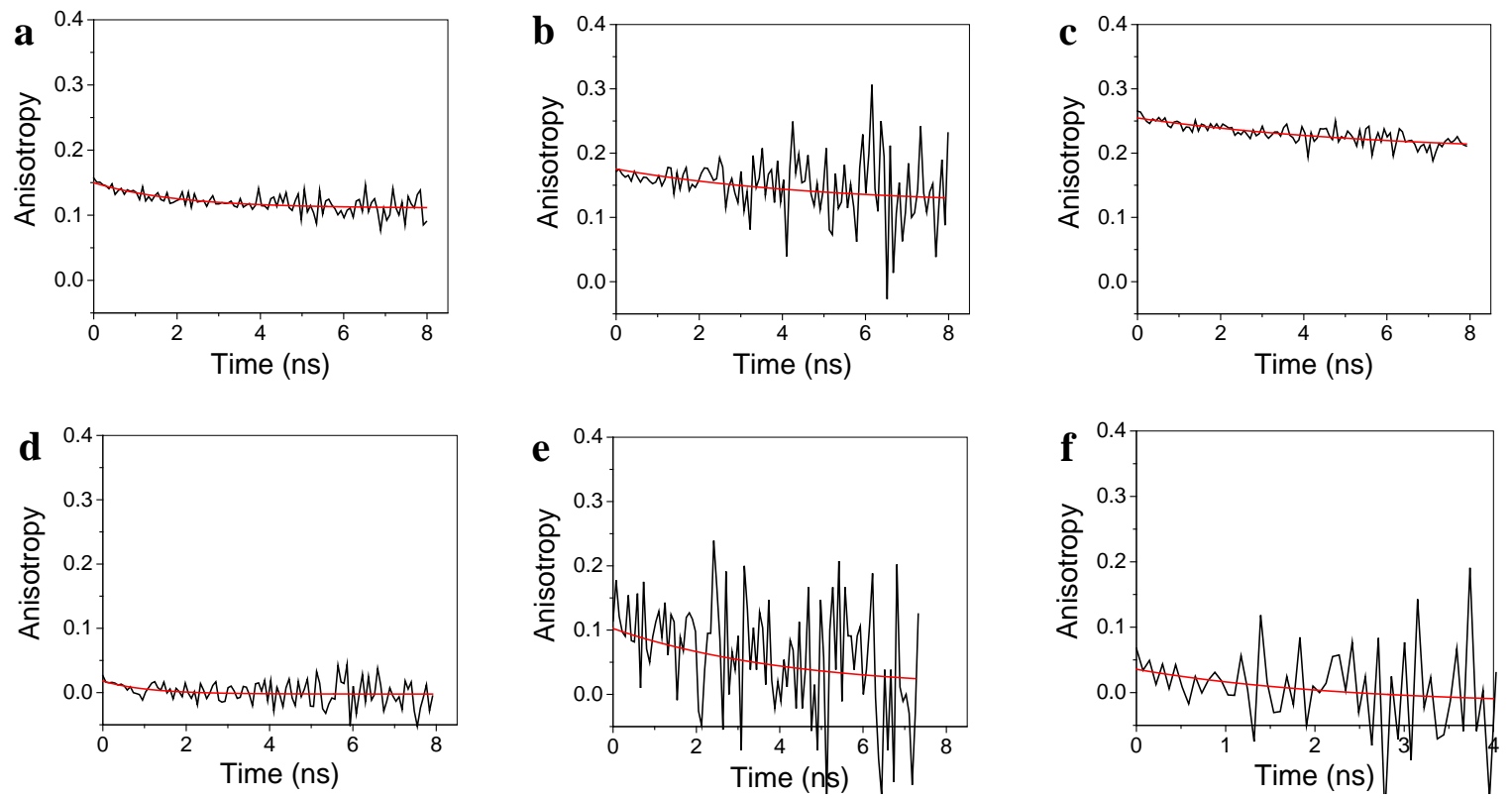

Figure S4. Fluorescence anisotropy of (a) 2, (b), 3, (c) 4, (d) 6, (e) 7, (f) 8 in the presence of DNA.
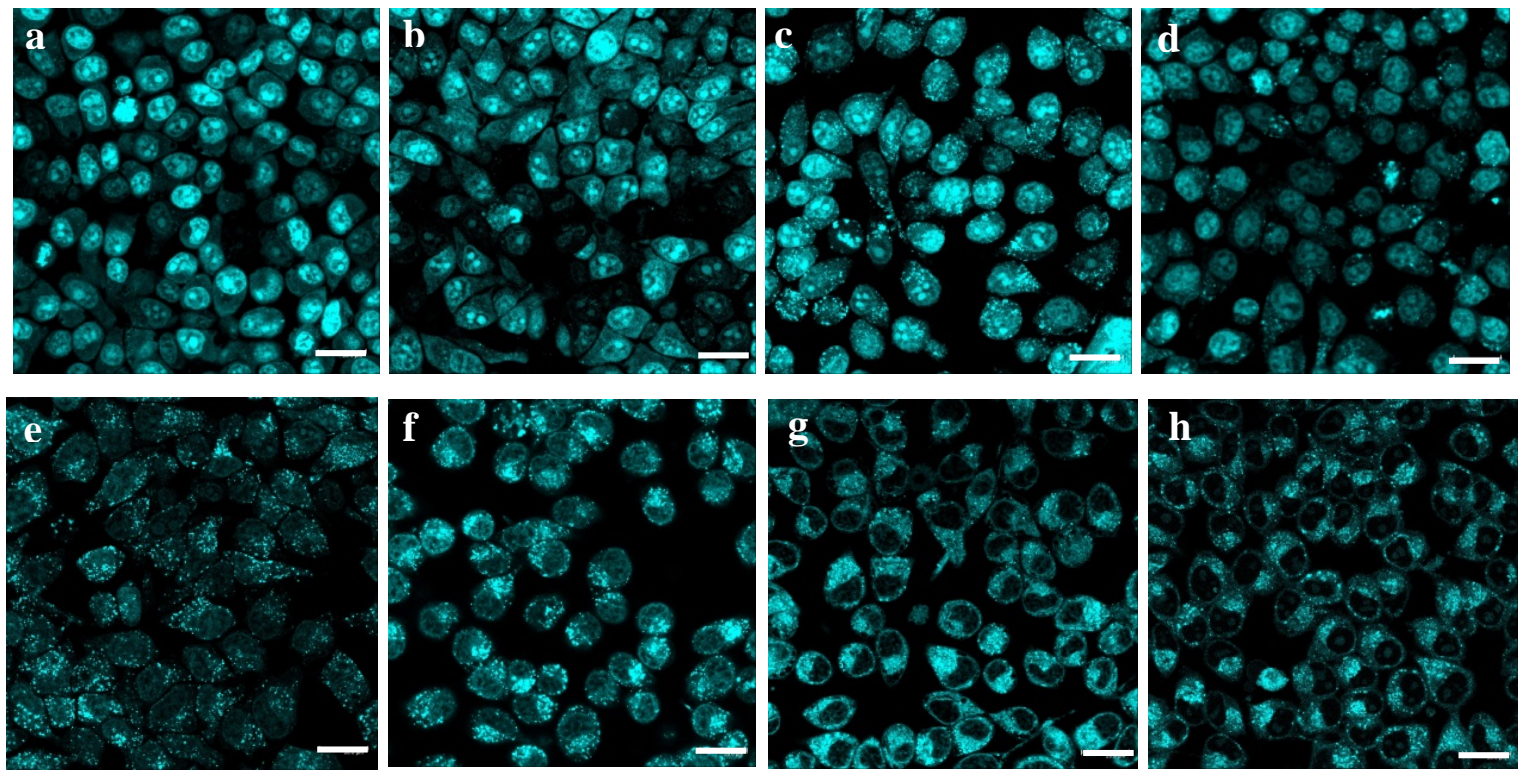

Figure S5. Single-photon excited fluorescence confocal microscopy images of live HeLa cells stained with (a) 1, (b) 2, (c) 3, (d) 4, (e) 5, (f) 6, (g) 7, (h) 8. The cells were incubated at $2 \mu \mathrm{M}$ of fluorophore for $1 \mathrm{~h}$. $\lambda_{\mathrm{ex}}=\lambda_{\text {max,abs. }}$ Bar: $20 \mu \mathrm{m}$. 
Synthesis of [2-[2,6-bis[(1E)-2-(4-methylpiperazin-1-yl)phenyl]ethenyl]-4-H-pyran-4ylidene]-propanedinitrile (8): $0.17 \mathrm{~g}$ (1.0 mmol) of 2-(2,6-dimethyl-4H-pyran-4-ylidene)propanedinitrile, $0.45 \mathrm{~g}$ ( $2.2 \mathrm{mmol})$ of 4-(4-methyl-1-piperazinyl)-benzaldehyde, $2.40 \mathrm{~g}$ (19.0 mmol) of TMS-Cl, and $10 \mathrm{ml}$ of anhydrous dimethylformamide were mixed in a $25 \mathrm{~mL}$ pressure tube with a magnetic stir bar. After heating at $90{ }^{\circ} \mathrm{C}$ for $48 \mathrm{~h}$, the reaction was cooled to room temperature and poured into a chilled solution of $1 \mathrm{M} \mathrm{NaOH}$; the resulting dark red precipitate was isolated by suction filtration and rinsed with water. The filtrate was crystallized twice from methanol and dried in an oven to yield $0.23 \mathrm{~g}$ (42\%) of 8 as a deep red powder. m.p: 296-298 ${ }^{\circ} \mathrm{C}$; IR $v_{\max }\left(\mathrm{cm}^{-1}\right)$ : 2791.64, 2204.35, 1635.96, 1595.66, 1537.87, 1487.56, 1331.44, 1188.29, 1138.23, 828.66; ${ }^{1} \mathrm{H}$ NMR (500 MHz, DMSO-d ${ }_{6}$ ), $\delta$ (ppm): 2.22 (3H, s), 2.43 (broad s, 8H), 3.29 (broad s, 8H), 6.73 (2H), 6.98-7.00 (d, 4H, $J=10 \mathrm{~Hz}$ ), 7.11-7.14 (d, 2H, $J=15.0 \mathrm{~Hz}$ ), 7.65-7.68 (d, $2 \mathrm{H}, J=15.0 \mathrm{~Hz}), 7.67-7.69$ (d, $4 \mathrm{H}, J=8.6 \mathrm{~Hz}) ;{ }^{13} \mathrm{C}$ NMR $\left(125 \mathrm{MHz}\right.$, DMSO-d $d_{6}$, TFA), $\delta$ (ppm): 42.51, 44.95, 52.46, 55.34, 106.46, 115.07, 116.61, 117.40, 126.56, 130.17, 138.05, 151.08, 156.52, 159.96; HR-ESI (Q-TOF) m/z: calc'd for $\mathrm{C}_{34} \mathrm{H}_{37} \mathrm{~N}_{6} \mathrm{O}^{+}\left(\mathrm{M}+\mathrm{H}^{+}\right)$: 545.7105, found: 545.3012.

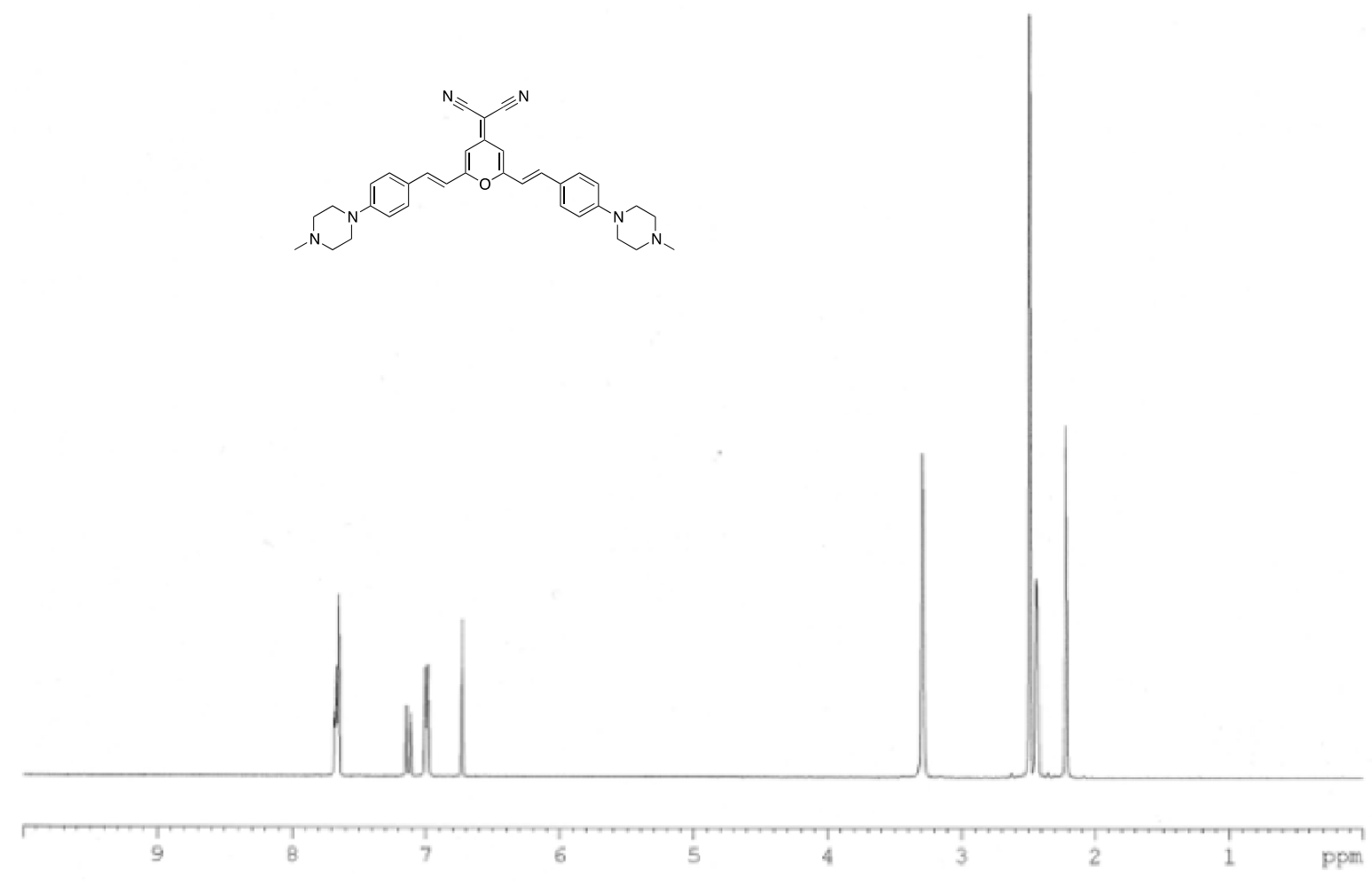

Figure S6. ${ }^{1} \mathrm{H}-\mathrm{NMR}$ spectra of 8. 


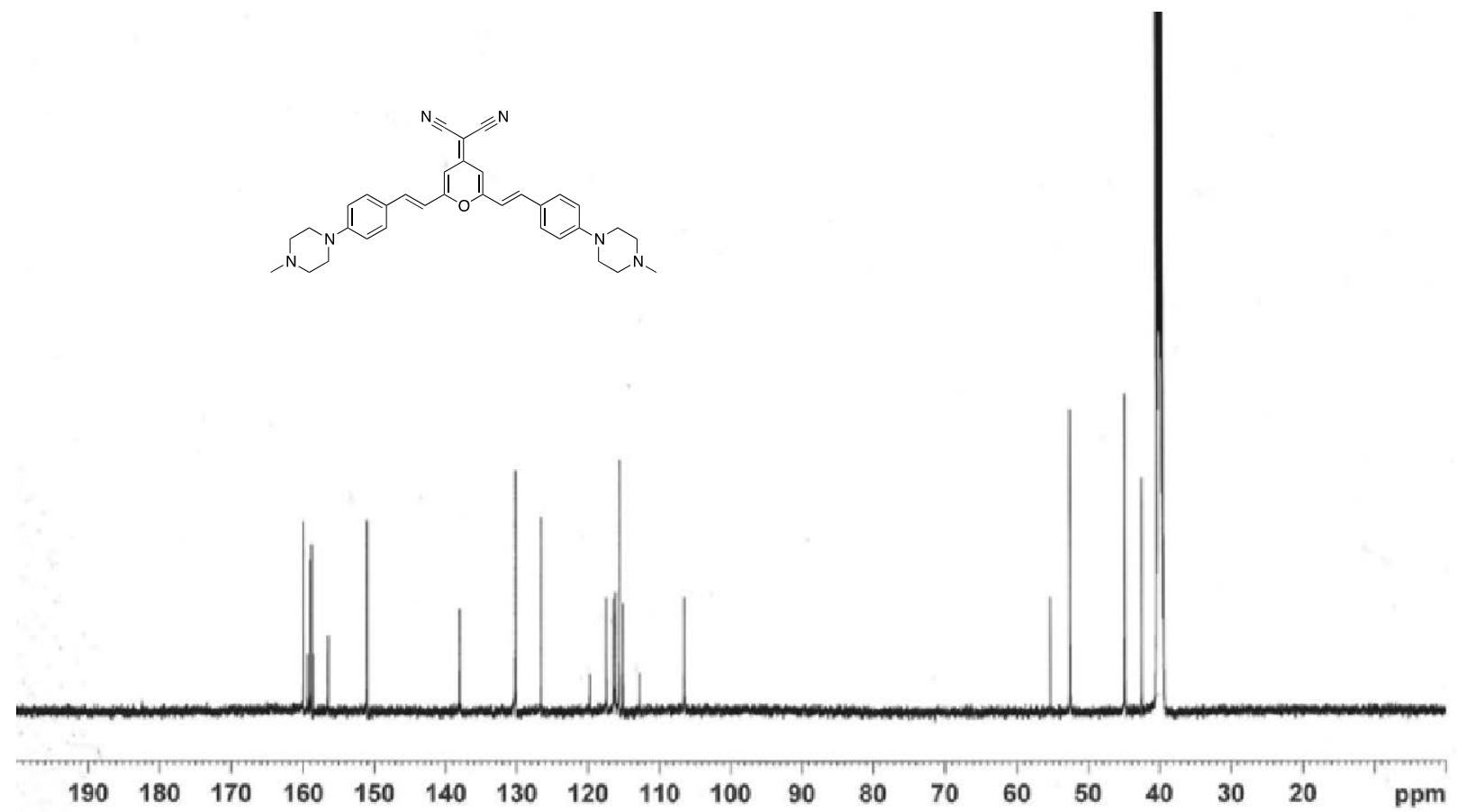

Figure S7. ${ }^{1} \mathrm{H}-\mathrm{NMR}$ spectra of 8 . 